\title{
Student's perception of school bullying and its impact on academic performance: A longitudinal look
}

\author{
Julieta Zalba, Student ${ }^{a}$, Lucas G. Durán, Student ${ }^{a}$, Diego R. Carletti, Student ${ }^{a}$, \\ Patxi Zavala Gottau, Student ${ }^{a}$, María G. Serralunga, B.S. ${ }^{b}$, Ezequiel F. Jouglard, \\ Master in Biochemistry and María E. Esandi, Master in Medicine ${ }^{a}$
}

\begin{abstract}
Introduction. Bullying among peers has immediate and long-term consequences, as it affects children's health-related quality of life. The aim was to examine the association between the frequency, type and dynamics of children's involvement in bullying situations and their academic performance over the school year.

Methods. Longitudinal study conducted in 2015 in 9 to 12 year-olds in schools of Bahía Blanca, Argentina. Outcome measures: children's involvement in bullying situations, frequency of participation in bullying and academic performance. Bullying categories were obtained through the Preconceptions of Bullying and Intimidation Among Peers (PRECONCIMEI) questionnaire and academic performance as reflected by each child's school grades.

Results. The survey included 375 children, of which $22.1 \%(83 / 375)$ were repeatedly involved and $30.12 \%(113 / 375)$ were occasionally involved in bullying situations $(20.27 \%$ [76/375] reported having participated by the year end but not at the beginning, and $9.85 \%$ [37/375] showed the opposite behavior). No statistically significant differences were found, regardless of the course subject analyzed. Grades were found to have improved by school year-end, in all groups assessed.

Conclusions. No association was found between bullying and academic performance.

Key words: school bullying, academic performance,
\end{abstract} child.

http:/ / dx.doi.org/10.5546/ aap.2018.eng.e226

a. Department of Health Sciences.

b. Department of Mathematics. Universidad Nacional del Sur. Bahía Blanca,

Argentina.

E-mail address:

Julieta Zalba, student: julietazalba@hotmail. com

Funding:

See page e222.

Conflict of interest: None.

Received: 4-3-2017 Accepted: 8-9-2017

To cite: Zalba J, Durán LG, Carletti DR, et al. Student's perception of school bullying and its impact on academic performance: A longitudinal look. Arch Argent Pediatr 2018;116(2):e216-e226.

\section{INTRODUCTION}

Bullying among peers is an act of unjustified aggressive behavior which, despite having different levels of severity, is always violent because it perverts the expected order in social relationships. It is characterized by the following three criteria: it is intended to cause harm; it repeats over time and it occurs in situations of power imbalance. It happens when a more powerful child or group of children attacks a less powerful child. Bullying can be physical, verbal, social and/or psychological abuse. ${ }^{1-3}$

In recent years, peer bullying has transcended the institutional setting to become a major public health problem on account of both its magnitude and the negative impact on the health of children involved in the short and long terms. ${ }^{1,2}$

Children who participate in these situations assume different roles: bully, bullied, bystander or bully and bullied, depending on the circumstances. The same child, however, may take on different roles over the year, which rules out the idea of a static profile. ${ }^{3-5}$

Based on a preliminary crosssectional study conducted in 2012 in a school in Bahía Blanca, Argentina, we carried out this survey, which was aimed at examining the association between frequency, type and dynamics of a child's involvement in bullying situations and his or her academic performance over the school year.

\section{POPULATION AND METHODS}

Prospective longitudinal study carried out in 2015 in seven schools in Bahía Blanca. The study population was made up of 9 to 12 year-old students in grades 4 to 6 in the seven participating schools (five public and two private institutions) selected by convenience sampling from among the city's 71 public primary and 29 private schools, according to the District Board of Education's criteria. Each school had different characteristics in terms of location, enrollment and desired education profile. 
School A: Strategically located, with a heterogeneous enrollment level (students came from different neighborhoods). It focused on diversity, an approach to current curricular contents, and rules of coexistence.

School B: Located downtown, with a high enrollment fee and middle and high socioeconomic level students. It focused on high-quality education and the peer-to-peer and student-teacher relationships.

School C: Located in the university district, with a varied enrollment level since many students were the children of professionals who had attended the Universidad Nacional del Sur. It focused on individual work based on each child's possibilities, high-quality education, and the peerto-peer and student-teacher relationships.

School D: Located on the outskirts of the city, attended by local children. It focused on community work and high-quality education.

School E: Located in an outlying neighborhood and attended by local children of middle to low socioeconomic levels. It focused on community and cooperative work.

School F: Located in an outlying neighborhood. Private catholic school run by the Salesian community. It featured a professional counseling team. The student population was mostly of middle socioeconomic level.

School G: Downtown location; private catholic school that featured a professional counseling team. Students came mostly from middle to high socioeconomic backgrounds.

Based on the data collected during the first and third quarters of school year 2015, children were classified based on their involvement in bullying situations (exposure variable). The exposed group was made up of children who reported having participated in bullying situations, repeatedly or occasionally, while the unexposed group was composed of those who reported having not. In each group, we described academic performance at the end of the first and third quarters, and at the end of the school year, and assessed its progression depending on the type of exposure.

Children aged 9 to 12 years attending the second cycle of primary education in these schools were eligible. Only children authorized to participate by their caregivers (by signed informed consent) were included; in addition, children had to give their assent to participate and be present on the day of the survey. Children with an intellectual disability that prevented them from understanding the questions were excluded, even if they had been authorized by their caregivers and had given their assent.

Data collection tools: The child version of the self-administered Preconceptions of Bullying and Intimidation Among Peers (PRECONCIMEI) questionnaire was used to measure exposure. It featured 14 items covering different dimensions (role, cause of bullying and situation-related aspects of bullying). The questionnaire was administered at school during class hours, in a separate room. Two members of the research team, different for each school, were present during questionnaire administration to explain the nature of the study to the children, ensure questionnaire confidentiality, and answer any question they had. The questionnaire was confidential but not anonymous; it contained a code identifying each child, only known by the research team assigned to each school. The PRECONCIMEI questionnaire was administered on two occasions, on the first and the third quarters of the school year. The date for questionnaire administration was strategically selected for each school so that it did not coincide with school events and group activities that would have resulted in absenteeism. The event of interest-academic performance-was measured on the basis of the average grade per subject and the general average grade. This data was obtained from high school sources (school records of the children enrolled in the study) made available by the authorities of each institution.

\section{Operational definition of outcome measures:}

- Child's involvement in bullying situations: It was assessed by means of the PRECONCIMEI. The "bullied" role was established based on children's affirmative answers to items 2, 3,5 , and 8 of the child version; the "bully" role, on affirmative answers to items 7 and 9; and the "bullied and bully" role, based on affirmative answers to the six questions; lastly, children were considered "not involved" if they answered no to all questions.

- Frequency of involvement in bullying situations based on children's perception (dynamism):It was assessed by analyzing both PRECONCIMEI measures, one at the beginning and another one at the end of the school year. When the child reported having participated in bullying in both questionnaire administrations (regardless of the type), such participation was defined as "repeated involvement"; if the child reported 
having participated in bullying only in the first or only in the second questionnaire administration, it was classified as "occasional involvement: involved-not involved" or "occasional involvement: not involvedinvolved", respectively; and if the respondent had not met participation criteria in any measurement, his/her participation was defined as "no active involvement".

- Overall and subject-specific academic performance: This outcome measure was assessed on the basis of school grades in Language Practice, Math, Social Sciences, Natural Sciences, English, Art Education and Physical Education for the first and third quarters of the school year, as well as the annual average grade.

\section{Statistical analysis}

To compare final grades for each subject among groups, based on the frequency of involvement in bullying situations, the analysis of variance (ANOVA) was used, with assumptions having been previously verified. In the analysis by subject, the difference in the grades of the first and third quarters was compared with the frequency of involvement categories using the Kruskal-Wallis test, as homoscedasticity was not verified. A value of $p<0.05$ was considered statistically significant. The analysis was done using the SPSS 23 software.

\section{Ethical considerations}

This research was approved by the Institutional Research Bioethics Committee of Hospital Municipal de Agudos “Dr. Leónidas Lucero" (HMALL) from Bahía Blanca, certified by the Central Ethics Committee of the Ministry of Health of the Province of Buenos Aires under no. $105 / 2013$. This study was approved by the authorities of the participating school. Prior to questionnaire administration, child assent and parent or caregiver informed consent were obtained. Grades were provided by the school principal using codes to avoid children identification and safeguard their anonymity.

\section{RESULTS}

\section{Study population}

At the beginning of the year, $99 \%$ of the eligible population $(1182 / 1186)$ were contacted. Only $40.53 \%$ (479/1186) of the eligible population gave their consent to participate. In the first questionnaire administration, $35.27 \%$ (417/1186) were included. In the second questionnaire administration, 375 of the 417 children participated, as contact was lost with 42 children. Finally, 375 children were included in the research: 183 boys and 192 girls (Figure 1). The average age of the entire population was 10.41 \pm 0.91 .

The characteristics of both groups are compared in Table 1. It is worth noting that none of the outcome measures showed statistically significant differences.

\section{Dynamics of peer involvement along the school year}

Of the 375 students who responded to both surveys administered in 2015,68\% (255/375) reported that they had not participated in bullying situations in the first questionnaire administration, while such percentage came down to $58 \%(216 / 375)$ in the second questionnaire administration.

Figure 1. Flow chart

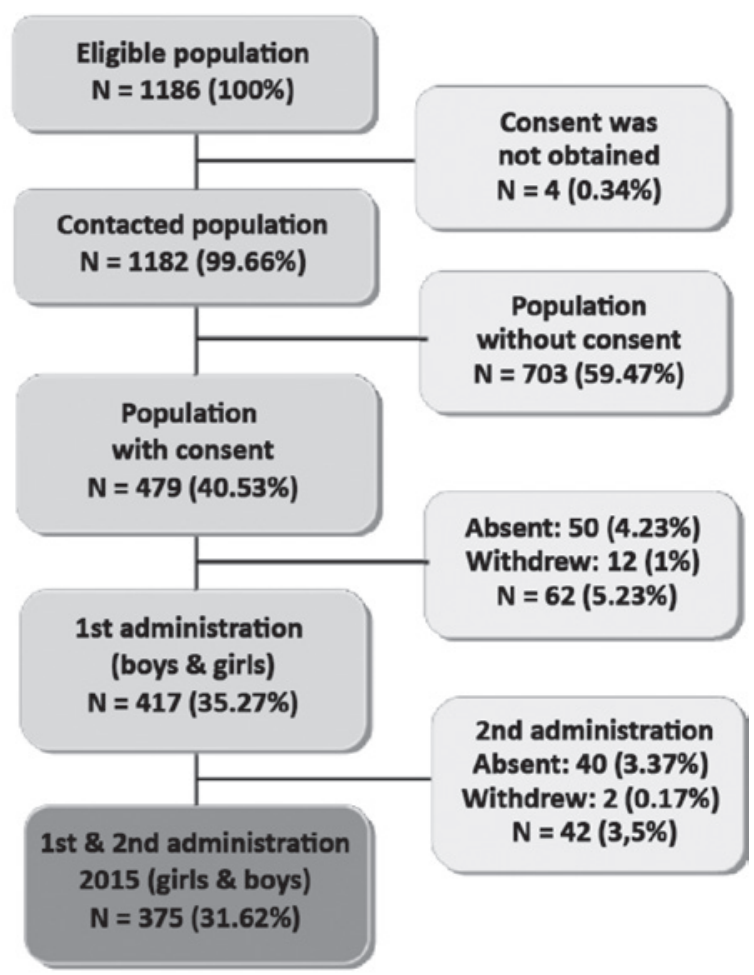

Source: Prepared by authors. 
Percentages of children's involvement in each bullying category, as defined in the PRECONCIMEI, are shown in Table 2.

It was found that $47.73 \%(179 / 375)$ had never been actively involved, $30.12 \%(113 / 375)$ had occasionally been involved, and $22.1 \%(83 / 375)$ had repeatedly been involved in a bullying situation. Children whose behavior changed from the first questionnaire administration to the second one (occasional involvement) accounted for $20.27 \%$ (76/375), with a worsening in their behavior, as they reported having participated in bullying at the end of the year but not at the beginning. Contrarily, 9.85\% (37/375) showed the opposite behavior (Table 2).

TABLE 1. Involvement by sex and school

\begin{tabular}{|c|c|c|c|c|c|c|}
\hline & $\begin{array}{c}\text { Repeated } \\
\text { involvement }\end{array}$ & $\begin{array}{c}\text { Involved- } \\
\text { not involved }\end{array}$ & $\begin{array}{c}\text { Not involved- } \\
\text { involved }\end{array}$ & $\begin{array}{c}\text { No active } \\
\text { involvement }\end{array}$ & Total & P value \\
\hline Boys & $45(24.6 \%)$ & $21(11.5 \%)$ & $37(20.2 \%)$ & $80(43.7 \%)$ & 183 & \multirow[t]{3}{*}{0.37} \\
\hline Girls & $38(19.8 \%)$ & $16(8.3 \%)$ & $39(20.3 \%)$ & $99(51.6 \%)$ & 192 & \\
\hline Total & $83(22.1 \%)$ & $37(9.9 \%)$ & $76(20.3 \%)$ & $179(47.7 \%)$ & 375 & \\
\hline School grade & & & & & & \\
\hline (Median) & 5 & 5 & 4.5 & 5 & & 0.08 \\
\hline \multicolumn{7}{|l|}{ School } \\
\hline A & 11 & 6 & 1 & 26 & 44 & \multirow[t]{7}{*}{0.32} \\
\hline $\mathrm{B}$ & 13 & 6 & 9 & 20 & 48 & \\
\hline $\mathrm{C}$ & 20 & 8 & 23 & 54 & 105 & \\
\hline $\mathrm{D}$ & 21 & 7 & 20 & 39 & 87 & \\
\hline $\mathrm{E}$ & 9 & 6 & 13 & 17 & 45 & \\
\hline $\mathrm{F}$ & 1 & 2 & 3 & 11 & 17 & \\
\hline G & 8 & 2 & 7 & 12 & 29 & \\
\hline Total & 83 & 37 & 76 & 179 & 375 & \\
\hline
\end{tabular}

TABLE 2. Dynamism of bullying situations

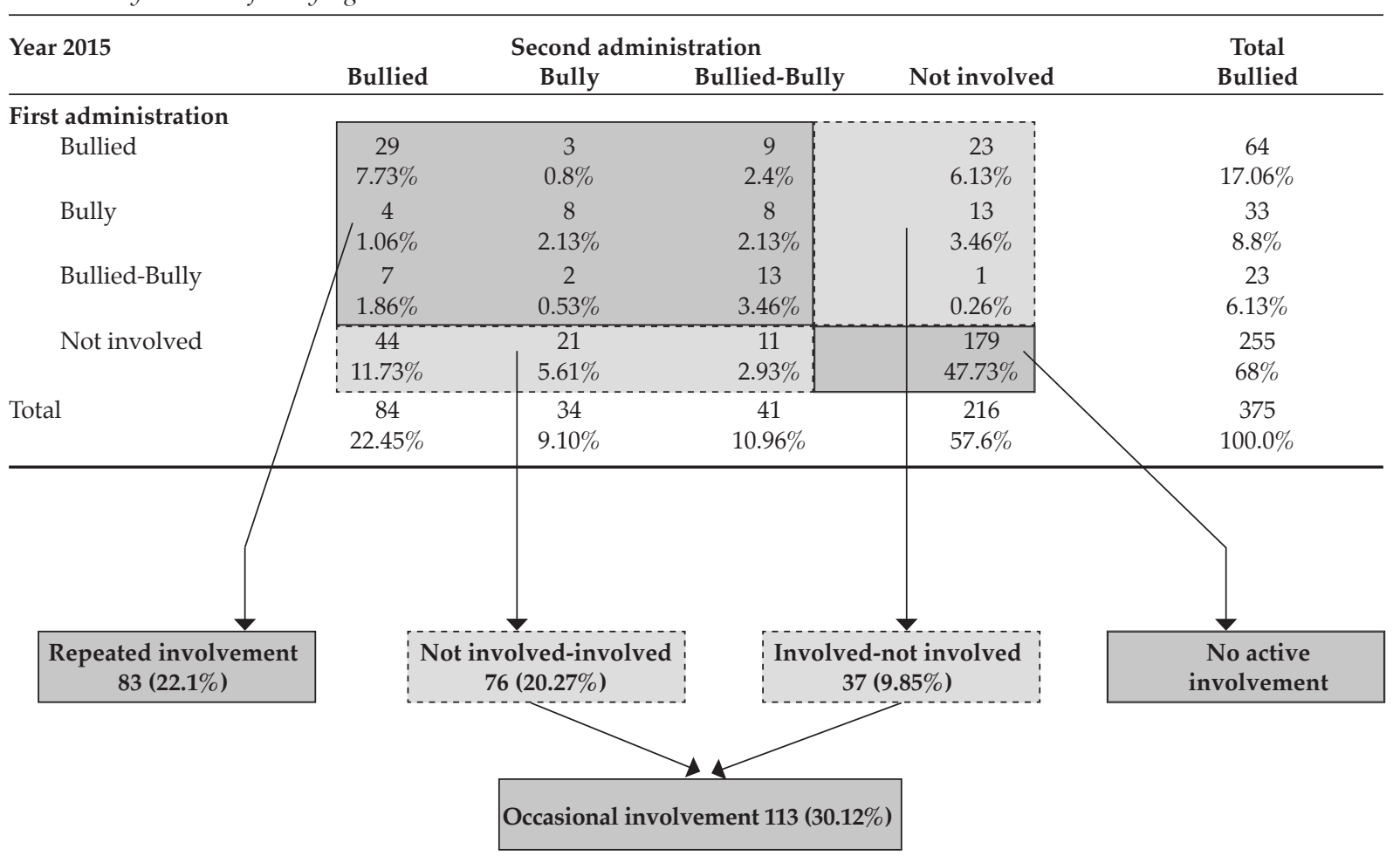




\section{Overall academic performance based on the involvement in bullying situations}

In analyzing each group's overall performance, a similar grade distribution was evidenced regardless of the role adopted by the child in each questionnaire administration. Physical Education and Art Education were the two subjects where children performed best, while they exhibited the poorest grades in Language Practice and Math.

In comparing final average grades, both overall and by subject, among categories of frequency of involvement in bullying situations, no statistically significant differences were detected (Figure 2).

The group who reported not having been involved in bullying in both questionnaire administrations was the one that exhibited the best academic performance at year-end, although such improvements over the school year were not statistically different for any of the subjects assessed when study groups were compared (Table 3). In addition, statistically significant differences were found in relation to final average grades in boys and girls. Boys achieved a final average grade of 8.20 and girls, 8.41 , with a mean difference of $-0 / 216$ and a confidence interval of $95 \%(-0.35 ;-0.83)$, with a $\mathrm{p}$ value of 0.02 . Thus, girls exhibited better academic performance than boys.

\section{DISCUSSION}

This was the first study conducted in our country aimed at analyzing the dynamics of peer bullying over an entire school year and its correlation with academic performance.

This longitudinal research evidenced no association between bullying and academic performance among public and private primary schools in Bahía Blanca, Argentina. All studied groups exhibited an improvement in school grades over the school year 2015.

Involvement in bullying situations was shown to impact on the health-related quality of life, regardless of the role assumed by the child; and

FIGURE 2. 95\% confidence intervals for overall average grade and subject-specific average grade in each study group

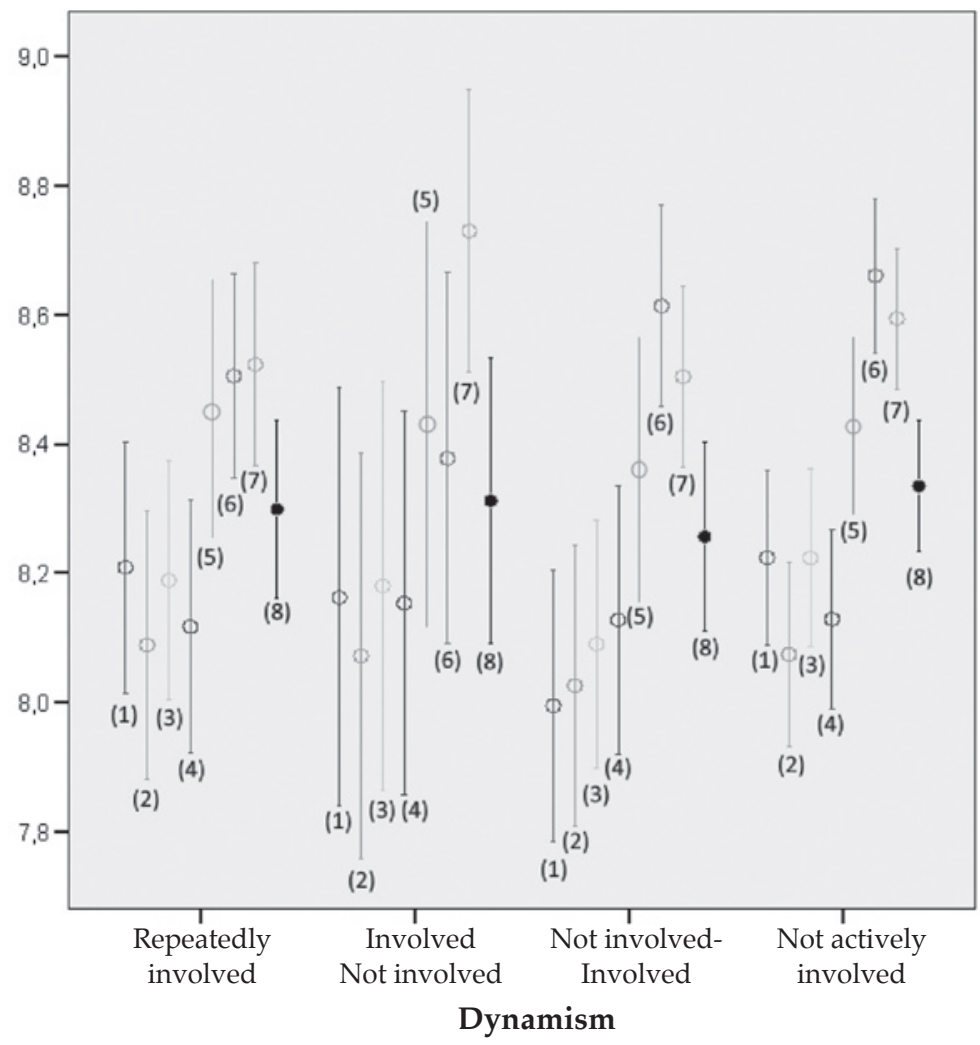
(1) LANG. FINAL
(2) MATH. FINAL
(3) NAT. FINAL
(4) SOC. FINAL
(5) ENG. FINAL
(6) ART FINAL
(7) PE. FINAL
(8) OVERALL

LANG.: Language Practice; NAT.: Natural Sciences; SOC.: Social Sciences; ENG.: English; ART: Art Education; PE: Physical Education 
such impact was directly proportional to the persistence of the child's participation. This is in line with what was reported by Olewus, who identified conditions ranging from depression to school social and academic integration problems in victims. ${ }^{3}$ In another study not pertaining to the project, 6 a decrease in academic performance associated with bullying was also observed. In turn, poor academic performance was suggested as a risk factor for the persistence of bullying situations in subsequent years. ${ }^{7}$

A young individual's academic performance entails not only correct exercise solving: there is a learning process that will allow him or her to figure it out, during which a wide range of tools are acquired. ${ }^{8,9}$ When these are not properly obtained, a disturbance occurs in learning and in the way of coping with everyday situations, resulting in a vicious circle.

The results of this study contradict other surveys in which a negative association is identified between both outcome measures..$^{10,11}$ A previous study carried out within the same research project determined lower grade averages in Language Practice and Math in children with reported involvement in bullying situations, which made it possible to determine the challenges these children were experiencing in the subjects relating to their cognitive and communicational development. ${ }^{12}$ A survey carried out in Chile in public and private schools on a sample of 84 students aged 8 to 12 years revealed that the greater the involvement in bullying situations, the lower the academic performance, particularly in Language Practice and Math. The reduced sample size may explain the significance of results. Although this study evidenced greater final academic performance in children who had not participated in bullying situations over the year (the "not involved-not involved" group), the difference with the rest of the groups was not statistically significant.

Since most studies mentioned above were cross-sectional, it was not possible to analyze the direction of the bullying-academic performance association or to consider the school bullying phenomenon as a dynamic process. In this study, only $30 \%$ of respondents changed their behavior from one questionnaire administration to the other, which was consistent with Gendrom's ${ }^{5}$ studies, where a dynamic pattern was identified (children usually took on different roles and could even become involved in this type of situations on an isolated basis). The dynamism that was not evidenced by other studies might be a determinant at the time of analyzing the relationship between these variables. In examining academic performance, it must be borne in mind that not all children learn at the same pace or with the same kind of teaching.

The present educational system uses a numeric scale to grade the student's extent

TABLE 3. Difference between grades of third and first quarters outcome measure. N: 375

\begin{tabular}{|l|l|l|l|l|l|}
\hline & \multicolumn{4}{|c|}{ Participación } & P value* \\
\hline $\begin{array}{l}\text { Repeatedly } \\
\text { involved } \\
\mathrm{N} 83\end{array}$ & $\begin{array}{c}\text { Involved-not } \\
\text { involved } \\
\mathrm{N} \mathrm{37}\end{array}$ & $\begin{array}{c}\text { Not involved- } \\
\text { involved } \\
\mathrm{N} \mathrm{76}\end{array}$ & $\begin{array}{c}\text { Not actively } \\
\text { involved } \\
\mathrm{N} 179\end{array}$ & \\
\hline $\begin{array}{l}\text { Language } \\
\text { practice }\end{array}$ & 0.51 & 0.46 & 0.51 & 0.56 & 0.920 \\
\hline Math & 0.36 & 0.38 & 0.29 & 0.41 & 0.811 \\
\hline $\begin{array}{l}\text { Natural } \\
\text { sciences }\end{array}$ & 0.42 & 0.19 & 0.39 & 0.54 & 0.051 \\
\hline Social sciences & 0.54 & 0.51 & 0.49 & 0.61 & 0.467 \\
\hline English & 0.37 & 0.24 & 0.55 & 0.35 & 0.431 \\
\hline Art education & 0.39 & 0.65 & 0.72 & 0.60 & 0.163 \\
\hline $\begin{array}{l}\text { Physical } \\
\text { education }\end{array}$ & 0.60 & 0.68 & 0.64 & 0.81 & 0.127 \\
\hline
\end{tabular}

$\left(^{*}\right)$ P value, Kruskal-Wallis test. 
of accomplishment of syllabus milestones. However, some authors claim that this evaluation method is hardly representative as it is intended to compare all students against an objective standard that generalizes learning, and there is a risk of underestimating each student's individual capacity. The focus should be placed on teaching children in such a way that they become creative individuals, who can develop good judgment and have the questioning and constructive attitude required to live in today's world. This becomes evident when performance is analyzed on a subject basis: Students performed best in Physical Education and Art Education regardless of their degree of involvement in bullying. ${ }^{13}$ This finding is consistent with the way in which these subjects are taught. In both Art Education and Physical Education, students have a handson participation in their learning, autonomy to decide what to do and how to do what is asked of them, which, in general, is consistent with their competences. ${ }^{14}$

The results obtained show that academic performance is the product of multiple factors, in line with what has been found by Cuevas, ${ }^{15}$ who characterizes it as the process conditioned by cognitive factors, learning styles, student's personal variables and family and institutional variables, which include the studentteacher relationship. Thus, a child's academic performance will not only be dependent on his or her academic setting but also on the evolution of his intellect and his or her social development.

One identified limitation is having assessed academic performance on the basis of the current grading system, as teachers are prone to increasing grades as the year progresses. In addition, other variables, such as student absenteeism and grade retention were not taken into consideration. This would have allowed for a more holistic look into academic performance.

\section{CONCLUSION}

This study confirmed the absence of an association between bullying and academic performance from a longitudinal perspective. No association was found in the analysis of the annual average grade or in the analysis of grade variation on the basis of the role assumed in bullying situations. This finding contradicts the literature; hence, further studies are needed for irrefutable conclusions to be reached in relation to this phenomenon.

\section{Funding}

This study was funded by the Universidad Nacional del Sur as part of a Research Group Project called "Assessment of bullying situations at school and their causal relationship to impaired mood in children aged 8 to 12 years old attending primary school." The grant received for the project was ARS 1157.

\section{REFERENCES}

1. Joffre-Velázquez V, García-Maldonado G, SaldívarGonzález A, et al. Bullying en alumnos de secundaria. Características generales y factores asociados al riesgo. Bol Med Hosp Infant Mex 2011;68(3):193-202.

2. Shetgiri R. Bullying and victimization among children. Adv Pediatr 2013;60(1):33-51.

3. Ortega Ruiz R, Mora-Merchán JA. Violencia escolar: Mito o realidad. Sevilla: Mergablum; 2000.

4. Zavala Gottau P, Carletti DR, Duran LG, et al. Dinámica de la Intimidación entre pares y su Impacto en la Calidad de Vida Relacionada a la Salud: Una Mirada Longitudinal. 26. ${ }^{\circ}$ Congreso Científico Argentinos de Estudiantes de Medicina. 14-17 de oct. de 2015; Buenos Aires, Argentina: UBA; 2015.Pág.18.

5. Gendron B, Williams K, Guerra N. An Analysis of Bullying Among Students within Schools: Estimating the Effects of Individual Normative Beliefs, Self-Esteem, and School Climate. J Sch Violence 2011;10(2):150-164.

6. Rettew DC, Pawlowski S. Bullying. Child Adolesc Psychiatr Clin N Am 2016;25(2):235-42.

7. Lien L, Welander-Vatn A. Factors Associated with the Persistence of Bullying Victimization From 10th grade to 13th grade: A Longitudinal Study. Clin Pract Epidemiol Ment Health 2013;9:243-50.

8. Mazur M. Dinámica bullying y rendimiento académico en adolescentes. Estudio Exploratorio. [Dissertation]. Montevideo: Universidad Católica del Uruguay; 2010.

9. Martorell C, González R, Rasal P, et al. Convivencia e inteligencia emocional en niños en edad escolar. Eur J Educ Psychol 2009;2(1):69-78.

10. Cerezo Ramírez F. Variables de personalidades asociadas en la dinámica bullying (agresores vs víctimas) en niños y niñas de 10 a 15 años. An Psicol 2001171:37-43.

11. Pérez-Fuentes MC, Álvarez-Bermejo JA, Molero MM, et. al. Violencia Escolar y Rendimiento Académico (VERA): aplicación de realidad aumentada. Eur J Investing Health Psychol Educ 2011;1(2):71-84.

12. Priani A, Zalba J, Esandi ME, et al. Intimidación entre niños y niñas de una escuela pública de la ciudad de Bahía Blanca y su relación con el rendimiento académico. Rev Asoc Méd Bahía Blanca 2016;26(2);50-6.

13. Pinkasz D, Montes N, Marcalain G, et al. Los usos de la información empírica en el sistema educativo: un estudio de caso en tres jurisdicciones de la Argentina. [Accessedon: September20th, 2017]. Available at: http: / / servicios2.abc.gov.ar/lainstitucion/sistemaeducativo/ educaciondeadultos/recursos_bibliograficos/gestion / los_usos_de_la_informacion_empirica_en_e_sistema_ educativo_un_estudio_de_caso_en_tres_jurisdiccio.pdf.

14. Spinosa M. Los saberes y el trabajo. Ensayo sobre una articulación posible. Seminario de Planteamiento y Gestión del sistema educativo. 2008. [Accessed on: September 20th, 2017].Available at: http:// servicios.abc.gov.ar/lainstitucion/univpedagogica/ especializaciones / seminario/materialesparadescargar/ seminario3bibliografia/seminario3 / archivos / Los $\% 20$ saberes $\% 20 y \% 20 \mathrm{el} \% 20$ trabajo_spinosa_.pdf.

15. Cuevas Jiménez A. La formación de alumnos como sujetos de bajo y alto rendimiento escolar en educación primaria. Rev Cub Psicol 2001;18(1):46-56. 


\section{ANNEX}

\section{Preconceptions of bullying and intimidation among peers (PRECONCIMEI)}

\section{CHILD VERSION}

1. In your opinion, what are the most common bullying or intimidation situations among classmates? (You may select more than one answer).

1. Insulting, nicknaming.

2. Laughing at and mocking someone.

3. Physically harming someone (pushing, kicking, punching).

4. Talking rubbish about someone.

5. Threatening and forcing someone to do things.

6. Rejecting, isolating, leaving someone aside.

7. Other forms of bullying.

8. There is no bullying among classmates in my school.

2. This year, how many times have you been bullied by one or more of your classmates? (Select ONLY ONE answer).

1. Never.

2. Few times.

3. Many times.

4. Almost every day, almost always.

3. If you have been bullied by your classmates, when did it start happening?

1. I have never been bullied.

2. Some time ago, a few weeks ago.

3. A few months ago.

4. Since the start of the school year.

5. It has always happened.

4. Where or how do these bullying situations usually occur? (You may select more than one answer).

1. During class, in the presence of the teacher.

2. During class, in the absence of the teacher.

3. In the school halls.

4. In the restrooms.

5. In the school yard, when there is a teacher supervising the place.

6. In the school yard, when there is no teacher supervising the place.

7. Near the school, on the way from school.

8. On the street.

9. On the Internet (Facebook, Twitter, e-mails).

10. On the telephone or mobile phone (texts, calls).

11. Nowhere.

5. If someone bullies you, do you tell anyone about it? (You may select more than one answer).

1. I am not bullied.

2. I do not tell anyone.

3. I tell the teachers.

4. I tell my family.

5. I tell my classmates. 
6. Who usually stops bullying or intimidation situations? (Select ONLY ONE answer).

1. No one.

2. A teacher.

3. An adult working at the school.

4. A male classmate.

5. A female classmate.

6. I don't know.

7. Have you ever bullied or intimidated a male or female classmate?

1. I never mess with anyone.

2. Occasionally.

3. Often.

4. Almost every day.

8. If you have been bullied or intimidated, why do believe that happened? (You may select more than one answer).

1. I have never been bullied or intimidated.

2. I do not know.

3. Because I provoked them.

4. Because I'm different from them.

5. Because I'm weaker.

6. To bother me.

7. To tease me.

8. Because I deserve it.

9. Because they think they are superior or better.

10. For some other reason:

9. If you ever were involved in situations of intimidation or bullying toward your classmates, why do you think you did it? (You may select more than one answer).

1. I haven't bullied anyone.

2. Because I was provoked.

3. Because other classmates bully/intimidate me.

4. Because they are different (foreigners, different race, etc.)

5. Because they were weaker.

6. Because I'm better than them.

7. To bother them.

8. To tease them.

9. For another reason:

10. Why do you think that some children intimidate or bully others?

1. To bother them.

2. Because they mess with them.

3. Because they are stronger.

4. Because they think they are superior or better.

5. To tease them.

6. For other reasons: 
11. How many times have bullying situations occurred in your school in the past three months? (Select ONLY ONE answer).

1. Never.

2. Less than 5 times.

3. Between 5 and 10 times.

4. Between 10 and 20 times.

5. More than 20 times.

6. Every day.

12. Who are the ones that usually bully or intimidate their classmates?

1. Nobody, there are no bullying situations in my class.

2. I do not know because I have never witnessed a bullying situation.

3. A male classmate.

4. A group of male classmates.

5. A female classmate.

6. A group of female classmates.

7. A group of male and female classmates.

13. If you ever witnessed a bullying situation, what did you do?

1. I have never witnessed a bullying situation.

2. I did nothing.

3. I tried to stop the bullies.

4. I told other classmates so that they knew what was happening.

5. I told the teacher or an adult.

6. I tried to help the bullied child so that bullying would stop.

7. I encouraged the bullies.

8. I did something else:

14. What do you think might solve this problem? (You may select more than one answer).

1. It cannot be solved.

2. I do not know.

3. Teachers should do something about it.

4. Families should do something about it.

5. Classmates should do something about it. 